\title{
Recognition of Inhaled Corticosteroids or Leukotriene Inhibitors as Controller Medications Among Older Adults and Its Association with Asthma Controller Medication Adherence
}

\author{
Grace E. Mclnerney, $\mathrm{BS}^{7}$, Rachel O'Conor, $\mathrm{PhD}, \mathrm{MPH}^{2}$, Michael S. Wolf, $\mathrm{PhD}, \mathrm{MPH}$, \\ Juan P. Wisnivesky, MD, DrPH ${ }^{3}$, and Alex D. Federman, MD, MPH \\ 'Icahn School of Medicine at Mount Sinai, New York, NY, USA; ${ }^{2}$ Division of General Internal Medicine, Feinberg School of Medicine, Northwestern \\ University, Chicago, IL, USA; ${ }^{3}$ Division of General Internal Medicine, Icahn School of Medicine at Mount Sinai, New York, NY, USA.
}

$\mathrm{J}$ Gen Intern Med 34(12):2705-7

DOI: $10.1007 /$ s11606-019-05305-y

(c) Society of General Internal Medicine 2019

\section{INTRODUCTION}

Asthma is common and debilitating in older adults. Suboptimal adherence to inhaled corticosteroids (ICS) contributes to morbidity in this population ${ }^{1}$ and may be the result of older adults' inability to distinguish controller from rescue medications as well as the regimens they should follow for each. In this study, we examined whether older asthmatics recognized their ICS as controller medications and tested the association of recognition with adherence.

\section{METHODS}

\section{Settings and Subjects}

Data were obtained from a trial of asthma self-management support for older asthmatics called Supporting Asthma selfManagement Behaviors among older Adults (SAMBA). Patients $\geq 60$ years with moderate or severe persistent asthma were recruited from primary care practices in New York City $(n=391)$. We excluded those with other pulmonary diseases, dependent on others for medication administration, or $>15$ pack-year smoking history. For this analysis, we included only those prescribed inhaled corticosteroids $(n=239)$. Interviews were conducted in-person in English or Spanish by bilingual research assistants. The institutional review boards of the participating institutions approved the study.

\section{Measures}

We measured patients' recognition of their ICS (alone or in combination with long-acting bronchodilators) as a controller medication. The interviewer first oriented patients to the concepts of controller and rescue medications then displayed their actual controller medication and asked them to state whether it was a controller or a rescue drug.

Published online August 29, 2019
Medication adherence was measured using the 10-item Medication Adherence Rating Scale (MARS). Good adherence was defined as MARS $\geq 4.5$. $^{2}$ Asthma control was measured with the 5-item Asthma Control Test (ACT). ${ }^{3}$ Additional measures that might confound the association of recognition and adherence included health literacy using the Newest Vital $\mathrm{Sign}^{4}$ and cognition using the Montreal Cognitive Assessment $(\mathrm{MoCA}){ }^{5}$

\section{Statistical Analysis}

We compared characteristics of patients who did and did not recognize their ICS as a controller using standard bivariate tests of association. We fitted a logistic regression model to determine the multivariate association of subject characteristics with controller recognition. We used the same method to determine the association of controller medication recognition with adherence, adjusting for age, sex, race, English-speaking ability, health literacy, and MoCA score. All analyses were performed using SAS version 9.4 (SAS Institute, Inc., Cary, NC).

\section{RESULTS}

The mean age was 67.4 (6.8), $13 \%$ were male, $52 \%$ were Hispanic, 52\% had low health literacy, and 35\% had limited English proficiency (Table 1). Overall, $28 \%$ of patients did not recognize their controller medication as such, and these patients were more likely to be Hispanic $(59.7 \%$ vs. $49.4 \%, p=$ 0.04), have low English proficiency (49.3\% vs. $29.1 \%, p=$ 0.003 ), and be cognitively impaired (67.2\% vs. $44.8 \%, p=$ $0.01)$ than those who correctly labeled their controller medication.

In adjusted analysis (Table 2), patients were significantly less likely to recognize their controller medication if they were aged $\geq 80$ years (odds ratio (OR) $0.20,95 \%$ confidence interval (CI) 0.05 to 0.86 ), were black (OR $0.15,95 \%$ CI 0.03 to 0.79 ), or had low English proficiency (OR 0.26, 95\% CI 0.07 to 0.92 ).

Good adherence to controller medications was reported by $16.5 \%$. Patients who correctly identified their controller 
Table 1 Baseline Characteristics of Study Population

\begin{tabular}{|c|c|c|c|c|}
\hline \multirow[t]{2}{*}{$\overline{\text { Variable }}$} & \multirow{2}{*}{$\begin{array}{l}\text { All } \\
N(\%)\end{array}$} & \multicolumn{3}{|c|}{ Knowledge of Controller } \\
\hline & & $\begin{array}{l}\text { No } \\
N(\%)\end{array}$ & $\begin{array}{l}\text { Yes } \\
N(\%)\end{array}$ & $p$ \\
\hline & $\begin{array}{l}239 \\
(100)\end{array}$ & $\begin{array}{l}67 \\
(28.0)\end{array}$ & $\begin{array}{l}172 \\
(72.0)\end{array}$ & \\
\hline Age, mean (SD) & $\begin{array}{l}67.4 \\
(6.8)\end{array}$ & $\begin{array}{l}69.1 \\
(8.1)\end{array}$ & $\begin{array}{l}66.7 \\
(6.2)\end{array}$ & 0.09 \\
\hline \multicolumn{5}{|l|}{ Age category } \\
\hline 707 & 167 & $\begin{array}{l}41 \\
(61.2)\end{array}$ & $\begin{array}{l}126 \\
(73.3)\end{array}$ & 0.00 \\
\hline $70-79$ & $54(22.6)$ & $\begin{array}{l}15 \\
(22.4)\end{array}$ & $39(22.7)$ & \\
\hline $80+$ & $18(7.5)$ & $\begin{array}{l}11 \\
(16.4)\end{array}$ & $7(4.0)$ & \\
\hline Male sex & $32(13.4)$ & $\begin{array}{l}12 \\
(17.9)\end{array}$ & $20(11.6)$ & 0.2 \\
\hline $\begin{array}{l}\text { Race and ethnicity } \\
\text { White }\end{array}$ & & & & \\
\hline $\begin{array}{l}\text { White, non-Hispanic; } \\
\text { other }\end{array}$ & $32(13.4)$ & $3(4.5)$ & $29(16.9)$ & 0.04 \\
\hline Black, non-Hispanic & $82(34.3)$ & $\begin{array}{l}24 \\
(35.8)\end{array}$ & $58(33.7)$ & \\
\hline Hispanic & $\begin{array}{l}125 \\
(52.3)\end{array}$ & $\begin{array}{l}40 \\
(59.7)\end{array}$ & $85(49.4)$ & \\
\hline \multicolumn{5}{|l|}{ Education } \\
\hline $\begin{array}{l}\text { Some high school } \\
\text { or less }\end{array}$ & $91(38.1)$ & $\begin{array}{l}32 \\
(47.8)\end{array}$ & $59(34.3)$ & 0.06 \\
\hline High school graduate & $56(23.4)$ & $\begin{array}{l}17 \\
(25.4)\end{array}$ & $39(22.7)$ & \\
\hline Some college & $53(22.2)$ & $\begin{array}{l}13 \\
(19.4)\end{array}$ & $40(23.3)$ & \\
\hline College & 39 (16.3) & $5(7.4)$ & $34(19.8)$ & \\
\hline Low English proficiency & $83(34.7)$ & $\begin{array}{l}33 \\
(49.3)\end{array}$ & $50(29.1)$ & 0.003 \\
\hline \multicolumn{5}{|l|}{ Health literacy ${ }^{\dagger}$} \\
\hline Limit & $98(52.4)$ & $\begin{array}{l}20 \\
(48.8)\end{array}$ & 78 (53.4) & 0.06 \\
\hline Possibility of limited & $63(33.7)$ & $\begin{array}{l}19 \\
(46.3)\end{array}$ & $44(30.1)$ & \\
\hline Adequate & $26(13.9)$ & $2(4.9)$ & $24(16.5)$ & \\
\hline Cognitive impairment & $\begin{array}{l}119 \\
(49.8)\end{array}$ & $\begin{array}{l}42 \\
(62.7)\end{array}$ & $77(44.8)$ & 0.01 \\
\hline $\begin{array}{l}\text { Given asthma action } \\
\text { plan }\end{array}$ & $42(17.6)$ & $7(10.5)$ & $35(20.4)$ & 0.07 \\
\hline $\begin{array}{l}\text { Asthma Control Test, } \\
\text { controlled }\end{array}$ & $32(13.4)$ & $9(13.4)$ & $23(13.4)$ & 1.0 \\
\hline $\begin{array}{l}\text { Brought medications } \\
\text { to interview }\end{array}$ & $\begin{array}{l}197 \\
(82.4)\end{array}$ & $\begin{array}{l}58 \\
(86.6)\end{array}$ & $\begin{array}{l}139 \\
(80.8)\end{array}$ & 0.3 \\
\hline $\begin{array}{l}\text { History of intubation } \\
\text { for asthma }\end{array}$ & $25(10.6)$ & $7(10.5)$ & $18(10.7)$ & 1.0 \\
\hline $\begin{array}{l}\text { Hospitalization for } \\
\text { asthma in past } \\
12 \text { months }\end{array}$ & $49(20.5)$ & $\begin{array}{l}10 \\
(14.9)\end{array}$ & $39(22.7)$ & 0.2 \\
\hline $\begin{array}{l}\text { Emergency department } \\
\text { visits for asthma in } \\
\text { past } 12 \text { months }\end{array}$ & $\begin{array}{l}108 \\
(45.2)\end{array}$ & $\begin{array}{l}34 \\
(50.8)\end{array}$ & $74(43.0)$ & 0.3 \\
\hline
\end{tabular}

${ }^{\dagger}$ Newest vital sign, limited (0-1), possibility (2, 3), adequate (4-6)

${ }^{*}$ Cognitive impairment defined as MoCA score $<21$ for adults under

70 years old and $<20$ for adults aged 70 or older

medication were more likely to be adherent than those who did not $(21.1 \%$ vs. $4.6 \%, p=0.002)$. This association remained statistically significant in multivariable analysis (OR 4.66, 95\% CI 1.32 to $16.49, p=0.001)$.

\section{DISCUSSION}

Daily use of controller medications is a cornerstone of management of persistent asthma, yet $28 \%$ of individuals prescribed a
Table 2 Predictors of Recognition of Controller Medication: Adjusted Analysis

\begin{tabular}{ll}
\hline \hline Factors & Odds ratio $(\mathbf{9 5 \%} \mathbf{C I})$ \\
\hline Age, years & \\
$\quad 60$ to 69 & 1.00 (referent) \\
70 to 79 & $0.62(0.24-1.61)$ \\
$80+$ & $0.20(0.05$ to 0.86$)$ \\
Sex & $0.38(0.14$ to 1.04$)$ \\
$\quad$ Male & 1.00 (referent) \\
Race/ethnicity & $0.15(0.03$ to 0.79$)$ \\
$\quad$ White, non-Hispanic; other & $0.54(0.08$ to 3.45$)$ \\
$\quad$ Black, non-Hispanic & $0.26(0.07$ to 0.92$)$ \\
Hispanic & $1.00($ referent $)$ \\
English ability & $0.23(0.05$ to 1.16$)$ \\
Very poor to fair & $0.58(0.11$ to 2.99$)$ \\
$\quad$ Adequate & \\
$\quad$ Possibility of limited & Limited \\
MoCA score & \\
$\quad$ Cognitively impaired & $0.84(0.38$ to 1.89$)$ \\
\hline
\end{tabular}

${ }^{\dagger}$ Cognitive impairment defined as MoCA score $<21$ for adults under 70 years old and $<20$ for adults aged 70 or older

controller were unable to recognize it as such. Those who correctly recognized their controllers were more likely to report controller adherence. The controller and rescue concepts are used in asthma education programs and promulgated through guidelines, yet until now little was documented about whether adults make this distinction and how their ability to distinguish them relates to asthma medication taking behaviors. Prior research is limited to parents of asthmatic children but is consistent with our findings. One study found that $23 \%$ of parents misunderstood the concept of ICS for "prevention," and their children were less adherent. ${ }^{6}$ Our analysis is the first to extend this earlier work to adults with asthma.

Generalizability of the study findings is limited by its geographically narrow recruitment area and focus on AfricanAmerican and Latino adults over the age of 60 . Nonetheless, these are populations with high levels of asthma morbidity. Our findings suggest that educational interventions designed to improve asthma medication adherence in adults should emphasize the role of controller medications and clearly and repeatedly distinguish the purposes and uses of controller and rescue medications.

Corresponding Author: Alex D. Federman, MD, MPH; Division of General Internal Medicine, Icahn School of Medicine at Mount Sinai, New York, NY, USA (e-mail: alex.federman@mountsinai.org).

Funding information Patient Centered Outcomes Research Institute (PCORI AS-1307-05584), National Center for Advancing Translational Sciences of the National Institutes of Health (TL1TROO1434)

\section{Compliance with Ethical Standards:}

The institutional review boards of the participating institutions approved the study.

Conflict of Interest: Dr. Wisnivesky received consulting honorarium from Merck, Banook, Sanofi, Quintiles, and AstraZeneca and research grants from Sanofi and Quorum. All remaining authors declare that they do not have a conflict of interest. 


\section{REFERENCES}

1. Sofianou A, Martynenko M, Wolf MS, et al. Asthma beliefs are associated with medication adherence in older asthmatics. J Gen Intern Med. 2013;28(1):67-73.

2. Cohen JL, Mann DM, Wisnivesky JP, et al. Assessing the validity of selfreported medication adherence among inner-city asthmatic adults: the Medication Adherence Report Scale for Asthma. Ann Allergy Asthma Immunol. 2009;103(4):325-331.

3. Schatz M, Sorkness CA, Li JT, et al. Asthma Control Test: reliability, validity, and responsiveness in patients not previously followed by asthma specialists. J Allergy Clin Immunol. 2006;117(3):549-556.
4. Weiss BD, Mays MZ, Martz W, et al. Quick assessment of literacy in primary care: the newest vital sign. Ann Fam Med. 2005;3(6):514-522.

5. Nasreddine ZS, Phillips NA, Bedirian V, et al. The Montreal Cognitive Assessment, MoCA: a brief screening tool for mild cognitive impairment. J Am Geriatr Soc. 2005;53(4):695-699.

6. Farber HJ, Capra AM, Finkelstein JA, et al. Misunderstanding of asthma controller medications: association with nonadherence. J Asthma. 2003;40(1):17-25.

Publisher's Note Springer Nature remains neutral with regard to jurisdictional claims in published maps and institutional affiliations. 